\title{
Prevalence of Salmonella and their antibiotic susceptibility patterns in the District of Abidjan, Côte d'Ivoire
}

\author{
Aya Carole BONNY ${ }^{1 *}$, Alfred T.G. KAROU ${ }^{1}$, Moussa SANOGO ${ }^{2}$, Koua ATOBLA ${ }^{1}$ \\ and Sebastien L. AHONZO-NIAMKE ${ }^{1}$ \\ ${ }^{1}$ Laboratory of Biotechnology of department of Biosciences, UFR Biosciences, University of Cocody, \\ Abidjan, 22 P.O.Box 582 Abidjan 22, Côte d'Ivoire. \\ ${ }^{2}$ LANADA Central Veterinary Laboratory of Bingerville, P.O.Box 206 Bingerville, Côte d'Ivoire. \\ *Corresponding author; E-mail: bonnyayacarole@yahoo.fr
}

\begin{abstract}
A study was conducted to estimate the prevalence, antibiotic susceptibility and distribution of Salmonella strains in raw chicken gizzards in 11 municipalities (Abobo, Adjamé, Anyama, Attécoubé, Bingerville, Cocody, Koumassi, Marcory, Port-Bouët, Treichville and Yopougon) in the District of Abidjan. Sixty six (66) samples of chicken gizzards were collected between April and September 2012. From the total of 66 samples tested, Salmonella was isolated in $77.27 \%$ (51/66). One hundred and four strains (104) were isolated and fifteen distinct serotypes identified: Derby (18.9\%), Budapest (17\%), Essen and S. Kentucky (11.3\%), Hadar (9.4\%), Agona (7.5\%), Chester, Ruiru, Schwarzengrund (3.8\%), Aoto, Bargny, Elisabethville, Fortune, Poeslderf and Santiago (1.9\%). Serogroup O:4 was the most prevalent (67.3\%). Prevalence of other serogroups were $18.3 \%$ for $\mathrm{O}: 8,10.6 \%$ for $\mathrm{O}: 3,10,1.9 \%$ for $\mathrm{O}: 21,1 \%$ for $\mathrm{O}: 1,3,19$ and $\mathrm{O}: 13$. Antibiotic profiles of Salmonella spp. showed $93.37 \%$ of resistance to cotrimoxazole, $73.08 \%$ to tetracycline, $46.15 \%$ to ticarcilline, $35.58 \%$ to nalidixic acid and resistance rates $\leq 30 \%$ to chloramphenicol and ciprofloxacin. Strains were found susceptible to cefoxitim (100\%), cefotaxim (99.04\%), cephalotin (90.38\%), amoxicillin and amoxicillin/clavulanic acid $(92.31 \%)$ and gentamycin $(89.42 \%)$.
\end{abstract}

(C) 2014 International Formulae Group. All rights reserved.

Keywords: Salmonella, raw chicken gizzards, serogroups, antibiotic susceptibility, Côte d'Ivoire.

\section{INTRODUCTION}

Salmonella enterica are one of the most important foodborne pathogens, leading to millions of cases of enteric diseases, thousands of hospitalizations and deaths worldwide each year (Callaway et al., 2010). Salmonella includes more than 2500 different serotypes (Popoff et al., 2001). Salmonella species can cause systemic infection especially in children and immuno- compromised individuals, while healthy individuals suffer from symptoms such fever, diarrhea, nausea, abdominal pain and septicemia (Coburn et al., 2007; Willford et al., 2007).

The majority of the infections are associated with ingestion of contaminated foods such as eggs, chicken, beef, pork, milk products, fruits, and vegetables (Brands et al., 2005; Zhao et al., 2008). Poultry and poultry 
products are usually incriminated in human salmonellosis outbreaks cross-contamination of workers hands, working equipment and utensils, subsequent handling of the raw poultry carcasses and organs, and products together with the consumption of undercooked poultry meat could serve as the most frequent causes of infection by Salmonella reported in humans (Yildirim et al., 2011).

Salmonella is also a pathogen of significant importance in worldwide animal production and the emergence of antibioticresistant strains, due to indiscriminate use of antibiotics in animal feeds as growth promoters and therapeutic agents is a further threat to human and animal health (Forshell and Wierup, 2006). Salmonella species are becoming increasingly resistant to antibiotics, making it more difficult to treat patients with severe infections. This makes Salmonella serovars that are resistant to multiple antibiotics a continuous and an important subject area of research, and a major concern for food safety (Adzitey et al., 2011).

Isolates of Salmonella that are resistant to antimicrobial agents have become a worldwide health problem (Butaye et al., 2006; Parry and Threlfall, 2008).

The objective of this work was to determine the prevalence of Salmonella isolated from chicken gizzards in the District of Abidjan and the antibiotic resistance profiles of strains.

\section{MATERIALS AND METHODS Sampling}

A total of 66 batches of 20 raw chicken gizzards samples were collected from April to September 2012 in 11 municipalities (Abobo, Adjamé, Anyama, Attécoubé, Bingerville, Cocody, Koumassi, Marcory, Port-Bouët, Treichville and Yopougon) of the District of Abidjan Côte d'Ivoire. Samples were collected once per week in sterile plastic bags and transported to the laboratory within one hour after collection, in an ice chest for analysis upon arrival.

\section{Culture and identification of strains}

All strains were isolated according to the protocol described by standard ISO 6579 (ISO-6579, 2002). Ten grams of chicken gizzard were pre enriched in $90 \mathrm{~mL}$ of BPW (Buffered Peptone Water) (BIO-RAD) in a stomacher bag (AJ seward, London) and incubated at $37{ }^{\circ} \mathrm{C}$ for 24 hours. After incubation, $0.1 \mathrm{~mL}$ and $1 \mathrm{~mL}$ of pre enriched broth was added respectively to $10 \mathrm{ml}$ of Rappaport Vassilliadis broth (BIO-RAD) and to $10 \mathrm{ml}$ of Müller-Kauffman Tetrationate broth in tubes to provide enrichment. Tubes were incubated at $42{ }^{\circ} \mathrm{C}$ and $37{ }^{\circ} \mathrm{C}$ for 24 hours respectively for Rappaport Vassilliadis (RV10) broth and Müller-Kauffman Tetrationate (MKT) broth. From each of the two tubes (RV10 and MKT), Hektoen agar and Xylose-Lysin-Deoxycholate (XLD) agar in Petri dishes were streaked and incubated at $37{ }^{\circ} \mathrm{C}$ for 24 hours. The suspected colonies were tested for catalase and oxidase test, Gram control; and then identified on the reduced rack of LEMINOR constituted of four culture media (Kligler-Hajna/MannitolMobility/Urea indole/Simmons Citrate) (BIORAD).

\section{Serotyping}

Serotypes were determined by agglutination tests slide with sera group and immune antisera directed against antigens $\mathrm{O}$, $\mathrm{H}$ and Vi of Salmonella (BIO-RAD). Reading the results was made according to the Kauffmann White scheme (Grimont and Weill, 2007). Salmonella strains serogrouping was done by slide agglutination tests using poly $\mathrm{O}$ and groups $\mathrm{O}: 4 ; \mathrm{O}: 8 ; \mathrm{O}: 3,10 ; \mathrm{O}: 21 \ldots$ Antisera.

\section{Antimicrobial susceptibility testing \\ Salmonella strains were tested for their susceptibility to different antibiotics using the}


agar diffusion method as described by the Clinical Laboratory Standards Institute (CLSI, 2005). An inoculum was prepared with 3 or 4 colonies of pure culture onto nutrient agar (Mueller Hinton agar) in slope. These colonies were emulsified in a tube of $5 \mathrm{~mL}$ of physiological water in order to obtain a homogenous suspension of density equivalent to $0.5 \mathrm{Mc}$ Farland standards. A sterile swab was moistened in the bacterial suspension, and Miller-Hinton agar previously dried was seeded by swabbing the entire surface of agar by scoring tightened. The operation was repeated twice. The antibiotic disks were disposed onto the surface of the dried agar medium with a distance of $3 \mathrm{~cm}$ between disk and the agar was incubated for 18 to 24 hours. After incubation, agar plats were read by measuring the diameters of inhibition zones around each antibiotic disk with a graduated ruler. A reference Strain of E. coli ATCC 14028 was tested as a quality control for culture and susceptibility testing. According to the Clinical and Laboratory Standard Institute standard (CLSI, 2005), results were interpreted and transcribed by the terms: Susceptible (S), intermediated (I) and resistant (R). Strains resistant to 3 or more antimicrobials from different classes were considered as Multidrug-Resistant (MDR). The following antibiotics were tested: amoxicillin, amoxicillin/clavulanique acid, tircacilline, cephalothin, cefoxitin, cefotaxim, gentamicin, chloramphenicol, cotrimoxazole, nalidixic acid, ciprofloxacin and tetracycline.

\section{RESULTS}

\section{Serogrouping}

Salmonella was isolated from $77.27 \%$

of samples $(\mathrm{n}=51)$. Further analysis of Salmonella positive samples led to identification of 104 isolates: 20 were from Marcory municipality, 13 were from Koumassi municipality, 11 were from Abobo and Treichville, 10 were from Bingerville, 9 were from Cocody, 8 were from Adjamé and Attécoubé, 6 were from Port-Bouët and Yopougon and 2 from Anyama. Salmonella isolates was distributed in six (6) serogroups: O: 4 (B), O: 8 (C1), O: 21 (L), O: 13 (G), O: 3,10 (E1) and O: 1,3,19 (E2) (Table 1 and Figure 1). Serogroup O: 4 was the most commonly isolated $(67.31 \%)$, followed by serogroup O: 8 (18.27\%), serogroup O: 3,10 (10.58\%), serogroup O: $1,3,19$ (0.96\%), serogroup O: 13 (0.96\%) and serogroup O: 21 $(1.92 \%)$. Majority of Salmonella isolates in the 11 municiplities had antigen 0:4 (67.31\%) and antigen O:8 (18,27\%). These two antigens represent most of $85 \%$ of Salmonella isolates in the district of Abidjan.

\section{Antimicrobial susceptibility testing}

Among 104 Salmonella enterica isolates, 103 were resistant to 1-11 categories of antimicrobial agents that include $\beta$-lactams, Sulfonamides, Aminosides, Phenicols, Quinolons and Cyclines. Strain showed resistance to tetracycline (73.08\%), sulfonamide $(93.37 \%)$, nalidixic acid (35.76\%), ciprofloxacin (28.85\%), chloramphenicol $(29.80 \%)$ and gentamycin $(10.58 \%)$. Among the $\beta$-lactams, resistance to Tircacillin $(n=48)$ was found highest, followed by Amoxicillin or/and Amoxicillinclavulanic acid, and Cefalotin $(n=6)$. Contrariwise, one resistance was observed to the third generation of cephalosporins (cefotaxime $(n=1)$ ) (Table 2). $99.04 \%$ of isolates $(103 / 104)$ presented resistance to all antimicrobials tested, $7.77 \%$ (8/103) presented a single type of resistance. $28.16 \%$ (29/103) showed resistance to two classes of antimicrobials and $64.07 \%$ (66/103) were multidrug-resistant (Resistance to 3 or more antimicrobials). Twenty strains of the 66 multidrug-resistant strains were selected for the tests of antimicrobials resistance genes (Table 3). 
Table 1: Distribution of Serogroups of Salmonella isolated from raw chicken gizzards in the District of Abidjan.

\begin{tabular}{|c|c|c|c|c|c|c|}
\hline \multirow[t]{3}{*}{ Municipalities } & \multirow[t]{3}{*}{ Strains isolated } & \multicolumn{3}{|c|}{ OMA } & \multicolumn{2}{|c|}{ OMB } \\
\hline & & \multicolumn{3}{|c|}{$\mathrm{E}(0: 3,10$ and } & \multirow[b]{2}{*}{$\mathrm{C}(\mathbf{0 : 8 )}$} & \multirow[b]{2}{*}{ G $(0: 13)$} \\
\hline & & B $(0: 4)$ & $0: 1,3,19)$ & L (O: 21) & & \\
\hline Abobo & 12 & 8 & 0 & 0 & 4 & 0 \\
\hline Adjamé & 8 & 5 & 1 & 0 & 2 & 0 \\
\hline Anyama & 2 & 2 & 0 & 0 & 0 & 0 \\
\hline Attécoubé & 8 & 8 & 0 & 0 & 0 & 0 \\
\hline Bingerville & 10 & 6 & 0 & 0 & 4 & 0 \\
\hline Cocody & 8 & 3 & 1 & 0 & 3 & 1 \\
\hline Koumassi & 13 & 7 & 3 & 0 & 3 & 0 \\
\hline Marcory & 20 & 16 & 1 & 2 & 1 & 0 \\
\hline Port-Bouët & 6 & 2 & 2 & 0 & 2 & 0 \\
\hline Treichville & 11 & 7 & 4 & 0 & 0 & 0 \\
\hline Yopougon & 6 & 6 & 0 & 0 & 0 & 0 \\
\hline Total & 104 & 70 & 12 & 2 & 19 & 1 \\
\hline (\%) agglutinate & 100 & 67,31 & 11,54 & 1,92 & 18,27 & 0,96 \\
\hline
\end{tabular}


Table 2: Antimicrobial susceptibility patterns of Salmonella isolates of chicken gizzards in the District of Abidjan.

\begin{tabular}{|c|c|c|c|c|}
\hline \multirow[t]{2}{*}{ Famillies } & & \multirow[t]{2}{*}{ Drugs } & \multicolumn{2}{|c|}{ Salmonella $(\%) / \mathrm{N}=104$} \\
\hline & & & $\mathbf{R}$ & $\mathbf{S}$ \\
\hline \multirow{6}{*}{ Bêta-lactams } & \multirow{3}{*}{ Penicillins } & amoxicillin & $8(7,69 \%)$ & $96(92,31 \%)$ \\
\hline & & amoxicillin/ clavulanic acid & $8(7,69 \%)$ & $96(92,31 \%)$ \\
\hline & & Ticarcilline & $48(46,15 \%)$ & $56(53,85 \%)$ \\
\hline & \multirow{3}{*}{ Cephalosporins } & Cefalotin & $10(9,62 \%)$ & $94(90,38 \%)$ \\
\hline & & cefoxitim & $0(0 \%)$ & $104(100 \%)$ \\
\hline & & cefotaxim & $1(0,96 \%)$ & $103(99,04 \%)$ \\
\hline Aminosides & & gentamycin & $11(10,58 \%)$ & $93(89,42 \%)$ \\
\hline Phenicols & & chloramphenicol & $31(29,81 \%)$ & $73(70,19 \%)$ \\
\hline Sulfonamides & & cotrimoxazole & $97(93,37 \%)$ & $7(6,73 \%)$ \\
\hline \multirow[t]{2}{*}{ Quinolones } & & nalidixic acid & $37(35,58 \%)$ & $67(64,42 \%)$ \\
\hline & & ciprofloxacin & $32(30,77 \%)$ & $73(69,23 \%)$ \\
\hline Cyclines & & tetracycline & $76(73,08 \%)$ & $28(26,92 \%)$ \\
\hline
\end{tabular}

N: Number of strains isolated; R: Resistant; S: Susceptible. 
Table 3: Profile of resistance of 20 strains of Salmonella isolated from chicken gizzard in the District of Abidjan.

\begin{tabular}{|c|c|c|c|c|}
\hline Strains & Municipalities & Serogroups & Serovars & Profile of resistance \\
\hline R 211/A & Marcory & $\mathrm{O}: 4(\mathrm{~B})$ & ND & CfCSXTNalCip \\
\hline D 311/A & Adjamé & $\mathrm{O}: 3,10(\mathrm{E} 1)$ & ND & CTeSXTNal \\
\hline E 111/A & Port-Bouët & $\mathrm{O}: 4(\mathrm{~B})$ & Essen & AAMCTicSXTTe \\
\hline E 212/A & Port-Bouët & $\mathrm{O}: 8(\mathrm{C} 2-\mathrm{C} 3)$ & Kentucky & CfGSXTNalCipTe \\
\hline E 221/A & Port-Bouët & $\mathrm{O}: 8(\mathrm{C} 2-\mathrm{C} 3)$ & Kentucky & CfGSXTNalCipTe \\
\hline H $411 / B$ & Treichville & $\mathrm{O}: 3,10(\mathrm{E} 1)$ & ND & CfCTeSXTNalCip \\
\hline $\mathrm{H} 421 / \mathrm{F}$ & Treichville & $\mathrm{O}: 3,10(\mathrm{E} 1)$ & ND & CTeSXTNalCip \\
\hline $\mathrm{P} 412 / \mathrm{B}$ & Yopougon & $\mathrm{O}: 4(\mathrm{~B})$ & Derby & AAMCTicCfTeCip \\
\hline H 512/A & Treichville & $\mathrm{O}: 4(\mathrm{~B})$ & ND & TeSXTNalCipTic \\
\hline H 611/A & Treichville & $\mathrm{O}: 4(\mathrm{~B})$ & ND & TicTeSXTNalCip \\
\hline H 611/B & Treichville & $\mathrm{O}: 4(\mathrm{~B})$ & ND & TicTeSXTNalCip \\
\hline H 612/B & Treichville & $\mathrm{O}: 4(\mathrm{~B})$ & ND & TicTeSXTNalCip \\
\hline $\mathrm{H} 412 / \mathrm{A}$ & Treichville & $\mathrm{O}: 3,10(\mathrm{E} 1)$ & ND & TicCTeSXTNalCip \\
\hline D 412/A & Adjamé & $\mathrm{O}: 8(\mathrm{C} 2-\mathrm{C} 3)$ & ND & GSXTNalCipTeTic \\
\hline G 221/A & Bingerville & $\mathrm{O}: 8(\mathrm{C} 2-\mathrm{C} 3)$ & ND & AAMCTicCfGSXTNalCipTe \\
\hline D 512/A & Adjamé & $\mathrm{O}: 8(\mathrm{C} 2-\mathrm{C} 3)$ & Bargny & AAMCTicCfGSXTNalCipTe \\
\hline G121/D & Bingerville & $\mathrm{O}: 8(\mathrm{C} 2-\mathrm{C} 3)$ & Kentucky & AAMCTicCfGTeSXTNaCip \\
\hline G 212/A & Bingerville & $\mathrm{O}: 8(\mathrm{C} 2-\mathrm{C} 3)$ & ND & AAMCTicCfGSXTNalCipTe \\
\hline C 322/A & Cocody & $\mathrm{O}: 8(\mathrm{C} 2-\mathrm{C} 3)$ & Kentucky & AAMCTicCfGSXTNalCipTe \\
\hline $\mathrm{C} 211 / \mathrm{A}$ & Cocody & $\mathrm{O}: 8(\mathrm{C} 2-\mathrm{C} 3)$ & ND & AAMCTicCfCTXGCTeSXTNalCip \\
\hline
\end{tabular}

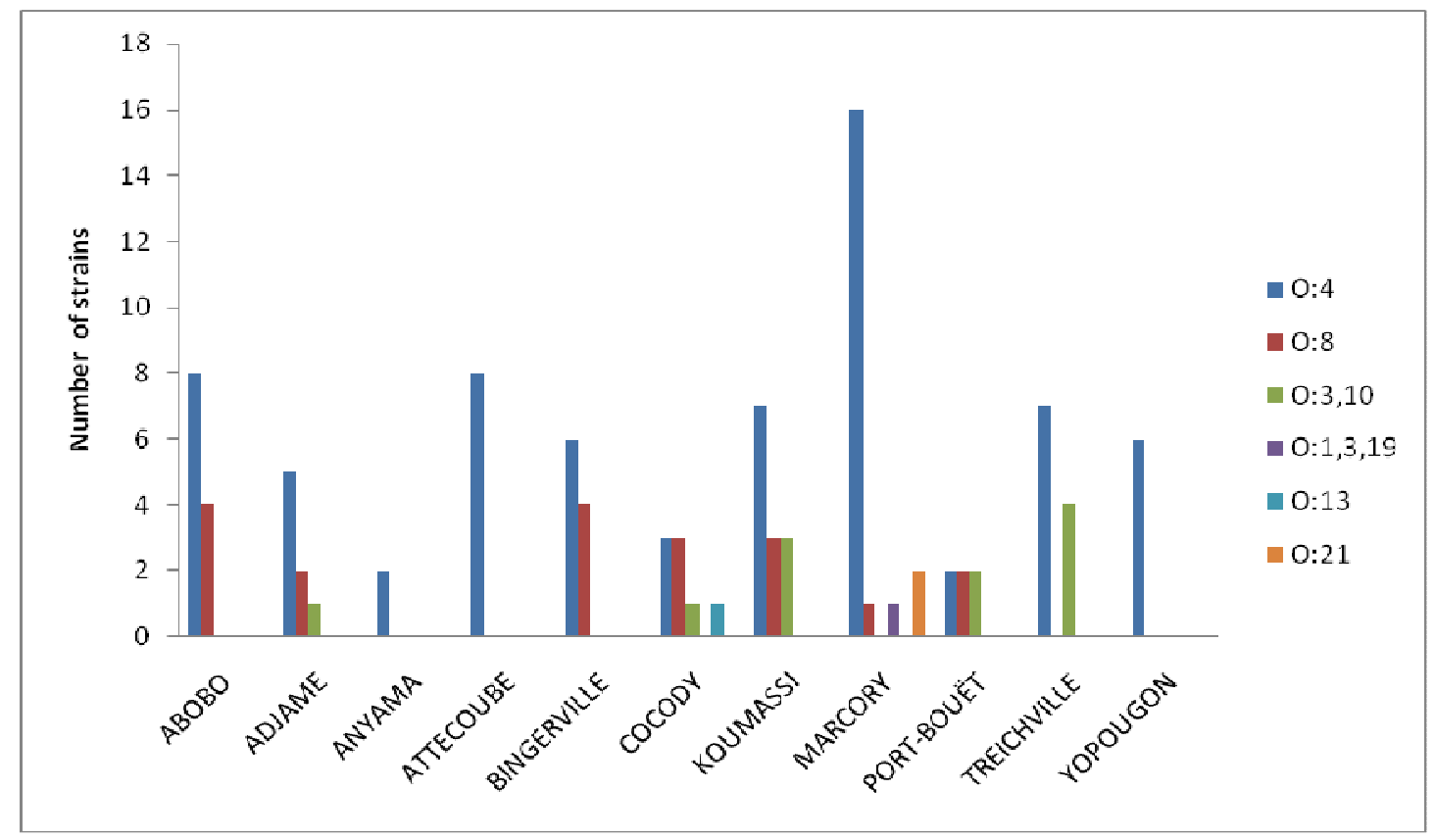

Figure 1: Distribution of Salmonella serogroups in the District of Abidjan, Côte d'Ivoire. 


\section{DISCUSSION}

The majority of strains of Salmonella isolated in our study possessed antigen O:4 with a proportion of $67.31 \%$, and antigen O:8 with proportion of $18.27 \%$. These two antigens (O:4 and O:8), represent most of $85 \%$ of Salmonella isolated. These rates presented similarly with studies conducted in some countries. A studies conducted in Turkey, revealed that Salmonella isolated from chicken carcasses also showed a high prevalence $(69.05 \%)$ for antigens O:4 and O:8 (Yildirim et al., 2011). Likewise in Algeria, an important presence of Salmonella strains isolated from chickens contained antigens O:4 and O:8, with proportion of $61.55 \%$ (Elgroud et al., 2008). In Malaysia, Salmonella strains isolated from ducks, showed also high proportion $(80 \%)$ of strains with antigens $0: 4$ and O:8 (Adzitey et al., 2011).

Salmonella are among the main pathogens involved in several reported cases of food toxiinfection. This is particularly the cas of salmonellosis due to Salmonella O:4, such as Salmonella Typhimurium linked to the consumption of undercooked beef (Dencos, 2000) and Salmonella Coeln linked to the consumption of poultry meat and beef in France (Haeghebaert et al., 1998). Several outbreaks of salmonellosis due to Salmonella Agona described in other countries, were linked to the consumption of powdered milk in the Czech Republic (Sramova et al., 1991) and France (Brouard et al., 2005) and herbal tea anise and fennel, in Germany (Koch et al., 2005). These cases of Salmonellosis were accompanied by nausea, vomiting and diarrhea. These observations indicate that, there is a probable link between the antigen O:4 and pathogenicity of the strain.

Other Salmonella infections were noted, particularly for strains with antigen O:8. Salmonella Kentucky for example, involved in an explosion of salmonellosis since 2002 in Europe and Africa, with poultry as primary vector (Le Hello et al., 2011). Salmonella Manhattan has also been involved in a large outbreak of salmonellosis associated with meat products of porcine origin in France (Noel et al., 2006). Similarly an outbreak of salmonellosis due to Salmonella Hadar, linked to consumption of undercooked poultry and roasted poultry in France (Decludt et al., 1995). These cases were also accompanied by diarrhea and gastroenteritis. These observations also indicate that, there is a probable link between antigen $0: 8$ and pathogenicity of the strain.

The study of the antibiotic susceptibility of Salmonella strains isolated showed high rates of resistance to cotrimoxazole and tetracycline. With tircacilline, nalidixic acid, ciprofloxacin and chloramphenicol, rates are relatively average compared to gentamycin, amoxicillin and amoxicillin/clavulanic acid. The level of antibiotic resistance observed in this study is comparable to those observed in Malaysia (Chen et al., 2004; Thong et al., 2002), and in Senegal (Toko, 2010).

The relatively high resistance obtained with fluoroquinolones in this study is comparable to those observed in Senegal (Fofana, 2004). The emergence of resistant strains to fluoroquinolones is due to their unreasonable use in the poultry field. Long-term treatment using antibiotic as Sulfonamides or Tetracyclines, and the use of criticism families for human medicine (cephalosporins and fluoroquinolones), promote the emergence of resistance in these molecules, especially with increasing use of enrofloxacin in poultry (Chauvin et al., 2005).

The emergence of strains resistant to multiple antibiotics has been reported in Salmonella serotypes associated with poultry (Antunes et al., 2003; Zhao et al., 2005).

The excessive and uncontrolled use of antibiotics may lead to the selection of resistant bacteria (Chaslus-Dancla, 2003). The development and emergence of resistance in pathogenic bacteria to humans and animals are the result of use of these molecules with poor understanding of the environmental impact of their use on the bacterial microflora (Sanders, 2005).

Salmonella strains isolated in Abidjan, with their two types of antigens (O:4 and O:8), could be considered as potential pathogens.

\section{Conclusion}

This study confirmed that the chickens' gizzards might act as the reservoirs for antimicrobial resistant bacteria. Therefore, to control the further emergence of antimicrobial resistance, monitoring the food processing and the careful use of antibiotics in animal husbandry is essential.

\section{ACKNOWLEDGEMENTS}

We acknowledge person in charge of the microbiology unit of central veterinary laboratory of Bingerville and unity of studies and research of chemical and microbiological contaminants in food of the Pasteur Institute in Côte d'Ivoire.

\section{REFERENCES}

Adzitey F, Rusul G, Huda N. 2011. Prevalence and antibiotic resistance of Salmonella serovars in 
ducks, duck rearing and processing environments in Penang, Malaysia. Food. Res. Int., doi:10.1016/j.foodres.2011.02.051.

Antunes P, Reu C, Sousa JC, Peixe L, Pestana N. 2003. Incidence of Salmonella from poultry products and their susceptibility to antimicrobial agents. Int. J. Food. Microbiol., 82: 97-103.

Brands DA, Inman AE, Gerba $\mathrm{CP}$, Maré CJ, Billington SJ, Saif LA. 2005. Prevalence of Salmonella spp. in oysters in the United States. Appl. Environ. Microb., 71: 893-897.

Brouard C, Espié E, Vaillant V, de Valk H. 2005. Epidémie de salmonellose à Salmonella enterica sérotype Agona chez des nourrissons liée à la consummation de poudres de lait infantile. InVs. 29

Butaye P, Michael GB, Schwarz S, Barrett TJ, Brisabois A, White DG. 2006. The clonal spread of multidrug-resistant non-Typhi Salmonella serotypes. Microbes. Infect., 8: 1891-1897.

Callaway TR, Edrington TS, Anderson RC, Byrd JA, Nisbet DJ. 2010. Gastro intestinal microbial ecology and the safety of our food supply as related to Salmonella. J. Anim. Sci., 86: 163 172.

Chaslus-Dancla E. 2003. Les antibiotiques en élevage : état des lieux et problèmes posés. INRA. http://www.tours.inra.fr/urbase/internet/ equipes/abr.htm

Chauvin C, Le Bouquin-Leneuve S, Hardy A, Haguet D, Orand JP, Sanders P. 2005. An original system for the continuous monitoring of antimicrobial use in poultry production in france. Journal of Veterinary Pharmacology and Therapeutics, 28: 515-523.

Chen S, Zaho SH, White DG, Schroeder CM, Lu R, Yang HC. 2004. Characterization of multipleantimicrobial-resistant Salmonella sérovars isolated from retail meats. Appl. Env. Microbiol., 70: 1-7.

CLSI. 2005. Performance Standards for Antimicrobial Susceptibility Testing (15th information supplement). CaLS Institute Ed.: Wayne, Pennsylvania.

Coburn B, Grass GA, Finlay BB. 2007. Salmonella, the host and disease: A brief review. Immunol. Cell. Biol., 85: 112-118.

Decludt B, Haeghebaert S, Bouvet P, Grimont PAD. 1995. Epidémie de salmonellose à Salmonella sérotype Hadar. B.E.H., 32: 140.

Dencos JC. 2000. Viande hachée de bœuf et salmonellose humaine: les enseignements de l'investigation de 3 épidémies et d'une enquête cas-témoins nationales. BEH., 36: 14.

Elgroud R, Zerdoumi F, Benazzouz M, Bouzitouna C, Granier S, Brisabois A, Dufour B. 2008. contaminations du poulet de chair par les salmonelles non typhiques dans les élevages et abattoirs de la Wilaya de Constantine. Sci.Tech. 27: $37-48$.

Fofana A. 2004. Etude de la resistance aux antibiotiques des souches de Salmonella sp et Escherichia coli isolees de la viande de poulet de chair au senegal. D.E.A, Universite Cheikh Anta Diop de dakar, Sénégal, p. 43.

Forshell LP, Wierup M. 2006. Salmonella contamination: A significant challenge to the global marketing of animal products. Rev. Sci. Tech. O.I.E., 25: 541-554.

Grimont PAD, Weill F. 2007. Antigenic Formulae of the Salmonella Serovars (9th edn). WHO Collaborating Centre for Reference and Research on Salmonella, Institut Pasteur: Paris

Haeghebaert S, Vaillant V, Portal H, Bouvet P, Minet JC, Grimont F. 1998. Epidémie de salmonellose à Salmonella enterica sérotype Coeln. BEH., 36: 14.

ISO-6579. 2002. Microbiologie des aliminentsméthode horizontale pour la recherche des Salmonella Spp., V08-013, 1-39.

Koch J, Schrauder A, Alpers K, Werber D, Frank C, Prager R. 2005. Salmonella Agona outbreak from contaminated aniseed, Germany. Emerg. Infect. Dis., 11: 1124-1127.

Le Hello S, Hendriksen RS, Doublet B, Fisher I, Nielsen EM, Whichard JM, Bouchrif B, Fashae K, Granier SA, Jourdan-Da silva N, Cloeckaert A, Threlfall EJ, Angulo FJ, Aarestrup FM, Wain J, Weill F. 2011. International Spread of an epidemic population of Salmonella enterica serotype Kentucky ST 198 resitant to Ciprofloxacin. J. Infect. Dis., 204(5): 675-684

Noel H, Dominguez M, Weill F, Brisabois A, Duchazeaubeineix C, Kerouanton A, Delmas G, Pihier N, Couturier E. 2006. Epidémie de salmonellose à Salmonella enterica sérotype Manhattan associée à des produits carnés. Eurosurv., 11: 3.

Parry CM, Threlfall EJ. 2008. Antimicrobial resistance in typhoid and non typhoidal salmonellae. Curr. Opin. Infect. Dis., 21: 531538.

Popoff MY, Bockemühl J, Brenner FW, Gheesling LL. 2001. Supplement 2000 (no.44) to the Kauffmann-White scheme. Res. Microbiol., 152: 907-909. 
Sanders P. 2005. L'antibiorésistance en médecine vétérinaire : enjeux de santé publique et de santé animale. Bull. Acad Vet., 158: 139-145.

Sramova H, Dedicova D, Petras P, Benes C. 1991. Epidemic occurrence of alimentary bacterial infections in the Czech Republic 1979-1989. Cesk. Epidemiol. Mikrobiol. Imunol. 40: 74-84.

Thong KL, Goh YL, Radu S, Noorzaleha S, Yasin K, Koh KT, Lim VKE. 2002. Genetic diversity of Clinical and environmental isolates of Salmonella enterica serotype Weltevreden isolated in Malaysia. J. Clin. Microb., 40: 24982503.

Toko MA. 2010. Evaluation du niveau de resistance de Salmonella spp d'origine aviaire a la tetracycline et au sulfamethoxazole. $\mathrm{PhD}$ thèse, faculté de médecine, de pharmacie et d'odontostomatologie de Dakar, Sénégal, p. 89.

Willford J, Manley W, Rebelein T, Goodridge LD. 2007. Pulsed field ribotype and intégron analysis of multidrug resistant isolates of Salmonella enterica sérovar Newport. Food. Res. Int., 40: 975-981.

Yildirim Y, Gonulalan Z, Pamuk S, Ertas N. 2011. Incidence and antibiotic resistance of Salmonella spp. on raw chicken carcasses. Food. Res. Int., 44: 725-728.

Zhao S, Fedorka-Cray PJ, Friedman S, Mcdermott PF, Walker RD, Qaiyumi S. 2005. Characterization of Salmonella Typhimurium of animal origin obtained from the National Antimicrobial Resistance Monitoring System. Food. Path. Dis., 2: 169-181.

Zhao S, White DG, Friedman SL, Glenn A, Blickenstaff K, Ayers SL. 2008. Antimicrobial resistance in Salmonella enterica serovar Heidelberg isolates from retail meats, including poultry, from 2002 to 2006. Appl. Environ. Microb., 74: 6656-6662. 